\title{
Expression and activity levels of chymase in mast cells of burn wound tissues increase during the healing process in a hamster model
}

\author{
XIANGLIN DONG ${ }^{1}$, TAO XU ${ }^{1}$, SHAOLIN MA ${ }^{1}$ and HAO WEN ${ }^{2}$ \\ ${ }^{1}$ Department of Burns and Plastic Surgery; ${ }^{2}$ State Key Laboratory Incubation Base of Xinjiang Major Diseases Research, \\ Clinical Medical Research Institute, The First Affiliated Hospital of Xinjiang \\ Medical University, Ürümqi, Xinjiang 830011, P.R. China
}

Received July 7, 2014; Accepted March 16, 2015

DOI: $10.3892 /$ etm.2015.2424

\begin{abstract}
The present study aimed to investigate the changes in the expression levels and activity of mast cell chymase in the process of burn wound healing in a hamster model of deep second-degree burn. The hamster model was established by exposing a $\sim 3 \mathrm{~cm}$ diameter area of bare skin to hot water $\left(75^{\circ} \mathrm{C}\right.$ ) for $0,6,8,10$ or $12 \mathrm{sec}$. Tissue specimens were collected $24 \mathrm{~h}$ after burning and histological analysis revealed that hot water contact for $12 \mathrm{sec}$ was required to produce a deep second-degree burn. Quantitative polymerase chain reaction and a radioimmunoassay were used to the determine changes in chymase mRNA expression levels and activity. The mRNA expression levels and activity of chymase were increased in the burn wound tissues when compared with the normal skin. However, no statistically significant differences were observed in mast cell chymase activity amongst the various post-burn stages. Chymase mRNA expression levels peaked at day 1 post-burn, subsequently decreasing at days 3 and 7 post-burn and finally increasing again at day 14 post-burn. In summary, a hamster model of deep second-degree burn can be created by bringing the skin into contact with water at $75^{\circ} \mathrm{C}$ for $12 \mathrm{sec}$. Furthermore, the mRNA expression levels and activity of chymase in the burn wound tissues increased when compared with those in normal skin tissues.
\end{abstract}

Correspondence to: Dr Hao Wen, State Key Laboratory Incubation Base of Xinjiang Major Diseases Research, Clinical Medical Research Institute, The First Affiliated Hospital of Xinjiang Medical University, 137 Liyushannan Road, Ürümqi, Xinjiang 830011, P.R. China

E-mail: dongxianglin8@21cn.com

Dr Shaolin Ma, Department of Burns and Plastic Surgery, The First Affiliated Hospital of Xinjiang Medical University, 137 Liyushannan Road, Ürümqi, Xinjiang 830011, P.R. China

E-mail: mashaolin9@163.com

Key words: hamster, chymase, burn wound

\section{Introduction}

Skin wound healing is a complex multifactorial process, involving inflammation, cell proliferation, cell migration, re-epithelialization, angiogenesis, extracellular matrix deposition and remodeling $(1,2)$. Burn wounds have a long healing period, and are the most representative persistent wounds for use in the study of skin wound healing. Deep second-degree burn wounds exhibit spontaneous epithelial regeneration through the proliferation and migration of the skin appendages under the wound and the epidermal cells around the wound margin (3). The healing period is relatively long; thus, deep second-degree burns are useful for the experimental study of burn wounds. Animal models of burn wounds have been used to study various pathological changes and healing mechanisms involved in the burn wound healing process (4).

Burn-induced tissue ischemia and inflammation can increase the number of mast cells in burn tissues (5) and stimulate mast cells to release vasoactive substances by degranulation (6). Mast cells play a role in the acute inflammatory phase and participate in wound healing together with fibroblasts $(7,8)$. Once activated, mast cells degranulate and release histamine, heparin and a variety of enzymes, such as chymase, cathepsin G and hydroxy peptidase A (9). Chymase is closely associated with tissue fibrosis.

Chymase is an $\alpha$-chymase-like serine protease that is involved in numerous physiological and pathophysiological processes. One of the most important functions of chymase is the regulation of angiotensin (Ang)II generation. In addition, chymase promotes myocardial and skin fibroblast proliferation $(10,11)$, the release of transforming growth factor- $\beta 1$ bound to the extracellular matrix and the degradation of procollagen protein that participate in tissue remodeling (12) and inflammation (13). Previous studies have shown that mast cell chymase is active during the healing process in burn wounds $(14,15)$. However, the changes in chymase expression levels and activity in the tissues during burn wound healing remain unclear. Human chymase differs to the chymase in the majority of other animals with regard to substrate specificity, with the exceptions of monkeys, dogs and hamsters (16-18). To the best of our knowledge, there have been no previous 
studies reporting the use of a hamster model in the study of burn wounds. In the present study, a hamster model of deep second-degree burn wound was established in order to study the association between mast cell chymase and the burn wound healing process.

\section{Materials and methods}

Hamster model for deep second-degree burn wound. A total of 24 hamsters (weight, 40-60 g; age, 8 weeks) were used, obtained from the Ürümqi Municipal Center for Disease Control and Prevention (Ürümqi, China). All animals were individually housed in stainless steel cages with a 12-h light-dark cycle and a controlled temperature. The hamsters received food and water ad libitum and were acclimatized for at least two weeks prior to thermal injury. All animal care and experimental procedures were approved by the Animal Ethics Committee of the First Affiliated Hospital of Xinjiang Medical University (Ürümqi, China).

The body surface areas of the hamsters (equivalent to $0.0913 \mathrm{x}$ weight $^{2 / 3}$ ) ranged between 106.8 and $139.9 \mathrm{~cm}^{2}$ (19). The burn wound was circular, with a diameter of $\sim 3 \mathrm{~cm}$, accounting for $5-6.5 \%$ of their body surface area. The hamsters were anesthetized with ketamine $(0.7 \mathrm{~g} / \mathrm{kg})$, and diazepam and atropine were used to maintain adequate anesthesia. Once anesthetized, the hair on the back of each hamster was removed to reveal a bare region with a diameter of $\sim 3 \mathrm{~cm}$. There are a variety of methods for producing deep second-degree burns in animal models (20-24); however, the majority of these methods are adapted to large animals and may be complex. The burn wound depth may be affected by the contact temperature, heat duration, burn area and pressure. Since hamsters are small in size, there is a risk of accidental mortality if the burn is not inflicted correctly. The end of a 50-ml syringe, with no plunger, was used to administer the burn. While the hamster was anesthetized, the end of the syringe was gently pressed onto the bare region on the back of the hamster to keep the hot water inside the syringe (Fig. 1A). Next, $20 \mathrm{ml}$ water $\left(75^{\circ} \mathrm{C}\right)$ was poured into the syringe, producing a circular burn wound with a diameter of $\sim 3 \mathrm{~cm}$. The durations of water contact with the back skin of the hamsters were $0,6,8,10$ and $12 \mathrm{sec}$, for the five groups of four hamsters. The wounds of all the hamsters were washed with running water for $1 \mathrm{~min}$ and $1.5-1.8 \mathrm{ml}$ isotonic saline was injected intraperitoneally for fluid resuscitation. The hamsters were insulated and received $700 \mathrm{mg} / \mathrm{kg}$ morphine when awake. The hamsters stopped experiencing any pain by day 2 after the burn was administered which was evident by their return to normal behavior. At $24 \mathrm{~h}$ after the burn, the wound tissues in the superficial layer of the deep fascia were removed, with the hamsters under ketamine anesthesia. The dissected tissues were immersed in $10 \%$ formaldehyde solution, with a volume ten times the volume of the tissues. The dissected tissues were divided into sections and stained with hematoxylin and eosin (H\&E). The optimum duration of hot water contact for producing a deep second-degree burn was determined by H\&E staining. According to the histologically determined durations of contact for deep second-degree burn, the wounds were created on the remaining four hamsters to observe wound healing durations.
$H \& E$ staining. Tissue samples were cut into slices for $\mathrm{H} \& \mathrm{E}$ staining. The sections were dewaxed with xylene for $15 \mathrm{~min}$ and soaked with $100 \%$ ethanol for $3 \mathrm{~min}, 95 \%$ ethanol for $3 \mathrm{~min}$ and $70 \%$ ethanol for $3 \mathrm{~min}$. The sections were then washed with water, air-dried, soaked with hematoxylin for $15 \mathrm{~min}$ and washed with water a further three times. Subsequently, the sections were stained with eosin for $3 \mathrm{~min}$ and soaked with $95 \%$ ethanol I for $3 \mathrm{~min}, 95 \%$ ethanol II for $3 \mathrm{~min}, 100 \%$ ethanol I for $3 \mathrm{~min}$ and $100 \%$ ethanol II for $3 \mathrm{~min}$. Once the ethanol had dried, the sections were soaked in xylene for $2 \mathrm{~h}$ and subsequently mounted using Permount ${ }^{\mathrm{TM}}$ Mounting Medium purchased from Multi Sciences (Lianke) Biotech Co., Ltd. (Hangzhou, China).

Quantitative polymerase chain reaction ( $q P C R)$. Total RNA was extracted with TRIzol ${ }^{\circledR}$ (Invitrogen Life Technologies, Carlsbad, CA, USA), chloroform, isopropanol and 75\% ethylene glycol, and stored in a refrigerator at $-80^{\circ} \mathrm{C}$. Reverse transcription was conducted by adding $1.5 \mu \mathrm{g}$ sample RNA to a 20- $\mu \mathrm{l}$ reaction system that included $1 \mu \mathrm{l}$ Oligo (dT) Primer, $1 \mu \mathrm{l}$ reverse transcriptase and $4 \mu \mathrm{l}$ buffer (Takara Biotechnology Co., Ltd., Dalian, China). The reaction mixture was incubated for $1 \mathrm{~h}$ at $37^{\circ} \mathrm{C}$ and then heated to $85^{\circ} \mathrm{C}$ for $5 \mathrm{~min}$ to terminate the reaction. For qPCR amplification, $5 \mu \mathrm{l}$ reacted solution was extracted and added to a $20-\mu 1$ reaction system that included $10 \mu \mathrm{l}$ SYBR Premix Ex Taq, $0.25 \mu 1$ target primer/0.25 $\mu 1$ $\beta$-actin primer (Takara Biotechnology Co., Ltd.) and $4.5 \mu 1$ $\mathrm{ddH}_{2} \mathrm{O}$. The reaction was conducted on a Thermal Cycler Dice Real Time System (Takara Bio, Inc., Otsu, Japan). For the amplification of chymase, the following PCR procedure was used: $95^{\circ} \mathrm{C}$ for $3 \mathrm{~min}, 35$ cycles of $95^{\circ} \mathrm{C}$ for $45 \mathrm{sec}, 55^{\circ} \mathrm{C}$ for $45 \mathrm{sec}$ and $72^{\circ} \mathrm{C}$ for $45 \mathrm{sec}$, and a final extension at $72^{\circ} \mathrm{C}$ for $5 \mathrm{~min}$. For the amplification of $\beta$-actin, the following PCR procedure was used: $95^{\circ} \mathrm{C}$ for $4 \mathrm{~min}, 35$ cycles of $95^{\circ} \mathrm{C}$ for $30 \mathrm{sec}, 60^{\circ} \mathrm{C}$ for $30 \mathrm{sec}$ and $72^{\circ} \mathrm{C}$ for $2 \mathrm{~min}$, and a final extension at $72^{\circ} \mathrm{C}$ for $7 \mathrm{~min}$. The PCR product was examined by dissociation curve analysis, and the relative quantification of gene expression was normalized against the internal standard, $\beta$-actin.

The primers were designed as follows: Chymase forward, 5'-CTG AGA GGA TGC TTC TTC CTG C-3', and reverse, 5'-AGA TCT TAT TGA TCC AGG GCC G-3'; $\beta$-actin forward, 5'-AAC TCC ATC ATG AAG TGT GA-3', and reverse, 5'-ACT CCT GCT TGC TGA TCC AC-3'.

Radioimmunoassay. Chymase activity in the burn tissue was determined using a radioimmunoassay (25). Burn tissue samples weighing $100 \mathrm{mg}$ were repeatedly homogenized and added to $50 \mathrm{mM} \mathrm{NaH} \mathrm{PO}_{4}$ buffer $(10 \mathrm{w} / \mathrm{v}, \mathrm{pH} \mathrm{7.4)}$ for $15 \mathrm{~min}$ at $4^{\circ} \mathrm{C}$. The samples were centrifuged at $3,000 \mathrm{x} \mathrm{g}$ for $20 \mathrm{sec}$ at $4^{\circ} \mathrm{C}$ and the supernatants were discarded. The sediments were added to $50 \mathrm{mM} \mathrm{NaH}_{2} \mathrm{PO}_{4}$ buffer for ultrasonic homogenization (400 A, $5 \mathrm{sec} /$ time with an interval of $10 \mathrm{sec}$, repeated three to five times) and the homogenized tissues were subsequently centrifuged at $30,000 \mathrm{x}$ g for $20 \mathrm{~min}$ at $4^{\circ} \mathrm{C}$. The homogenization and centrifugation steps were repeated three times and the supernatants, which contained chymase, were collected for each repeat. From each processed sample, $1,500 \mu \mathrm{l}$ supernatant was collected and divided into three tubes (500 $\mu \mathrm{l}$ each) labeled A, B and C. For reaction system A, 

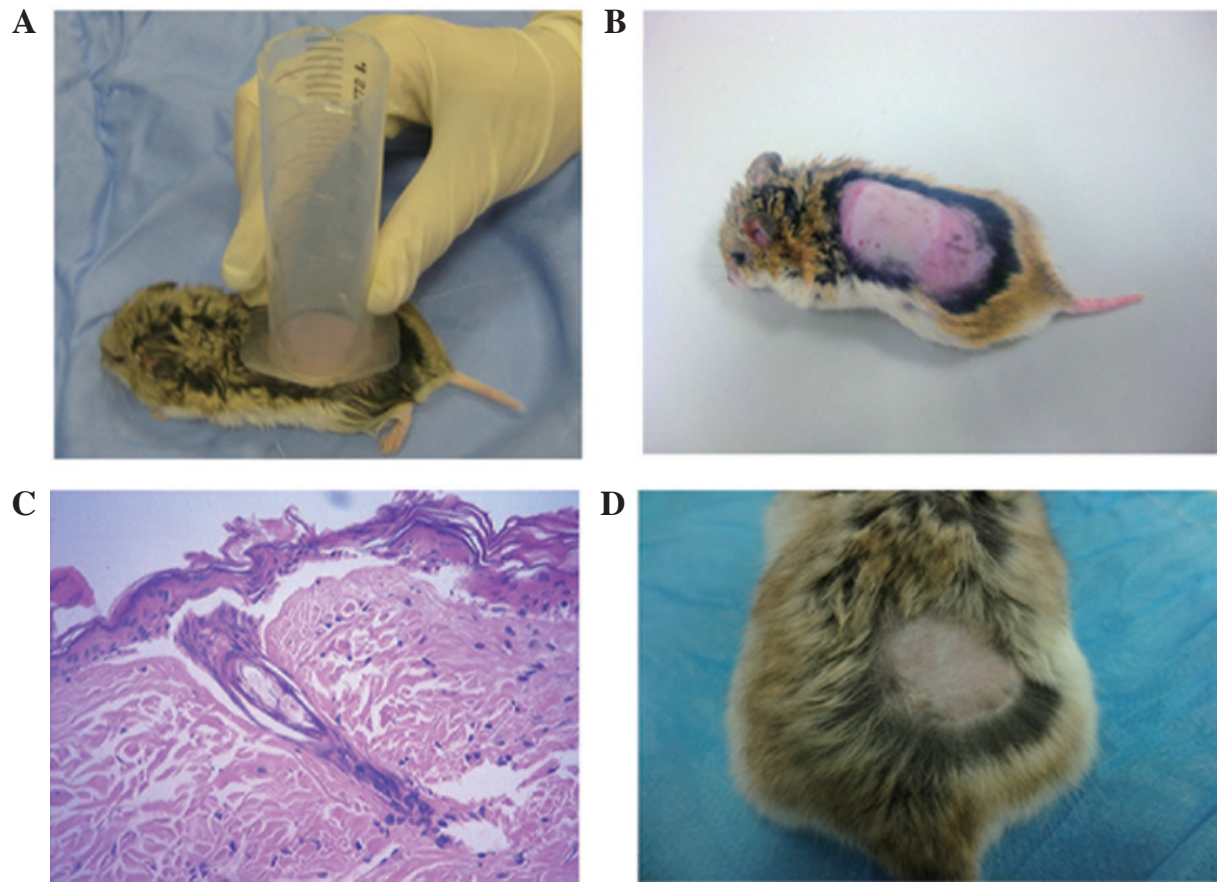

Figure 1. Establishment of a hamster model of deep second-degree burn wound. (A) Following anesthesia, the hair on the back of each hamster was removed, forming a bare region with a diameter of $\sim 3.5 \mathrm{~cm}$. The end of a $50 \mathrm{ml}$ syringe with no plunger was used as the burn template. Under anesthesia, the end of the syringe was gently pressed onto the bare region on the back of the hamster to keep the injected water inside the syringe. Next, $20 \mathrm{ml}$ water $\left(75^{\circ} \mathrm{C}\right)$ was injected into the syringe to create a circular burn wound with a diameter of $\sim 3 \mathrm{~cm}$. (B) Burns created by hot water contact for $12 \mathrm{sec}$. (C) Hematoxylin and eosin-stained image of the burn wound tissue $24 \mathrm{~h}$ after hot water contact for $12 \mathrm{sec}$ (magnification, x400). (D) Epithelialization of the burn wound at day 18 after the burn.
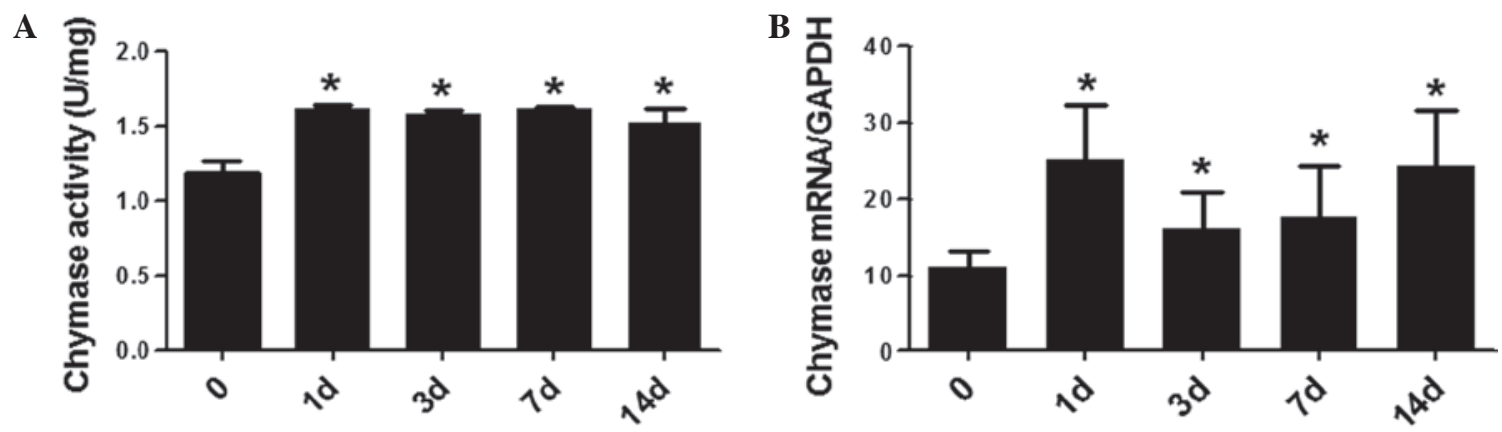

Figure 2. (A) Activity and (B) mRNA expression levels of chymase in the burn wound tissues at days $0,1,3,7$ and 14 after the burn. Data are expressed as the mean \pm standard deviation. ${ }^{*}<0.05$, vs. day 0 .

$6 \mathrm{ng}$ AngI was added, while $6 \mathrm{ng}$ AngI and $50 \mu \mathrm{M}$ lisinopril were added to reaction system B and 6 ng AngI and $20 \mu \mathrm{M}$ aprotinin were added to reaction system $\mathrm{C}$. The tubes were placed in a water bath $\left(37^{\circ} \mathrm{C}\right)$ for $15 \mathrm{~min}$, and a 2.5 -fold volume of precooled ethanol was added to terminate the reaction. The resulting concentrations of AngII in reaction systems A, B and $\mathrm{C}$ were determined using a radioimmunoassay kit (Beijing North Institute of Biological Technology, Beijing, China), according to the manufacturer's instructions. The activity of angiotensin-converting enzyme (ACE) was calculated by subtracting the enzyme activity of reaction system $B$ from that of A. The activity of other serine proteases was calculated by subtracting the enzyme activity of reaction system $\mathrm{C}$ from that of A. Finally, the activity of chymase was calculated by subtracting the ACE activity and the other serine protease activity from the enzyme activity of reaction system A. The enzyme activity required for the generation of $1 \mathrm{nmol}$ AngII in
$100 \mathrm{mg}$ burn tissues per min was defined as 1 enzyme activity unit (U). The activity of chymase was expressed as U/mg.

Statistical analysis. SPSS software, version 16.0 (SPSS, Inc., Madison, WI, USA) was used for statistical analysis. The results are presented as the mean \pm standard deviation. Analysis of variance and Dunnett's test were used to assess the differences between groups. $\mathrm{P}<0.05$ was considered to indicate a statistically significant difference.

\section{Results}

A hamster model of deep second-degree burn is established by hot water contact for $12 \mathrm{sec}$. To evaluate the degree of the burn wounds, hamsters were used as the animal model and H\&E staining of the tissues was performed. All hamsters used in the study survived. The degree of paleness of the burnt skin varied 
at different time periods after the injury was inflicted. At $24 \mathrm{~h}$ after the burn was inflicted, the edge of the burn wound was red with swelling, while the wound itself exhibited swelling and was white in color, with no visible blisters (Fig. 1B). The burn contact durations analyzed were $0,6,8,10$ and 12 sec. Histological examination revealed that the epidermal cells were partially detached from the burn area in the 12-sec burn duration hamsters. H\&E staining showed that the structure of the tissues was unclear and that blisters had formed on the skin. In addition, congestion had occurred in the dermal interstitial layer, collagen fibers had integrated into sheets and residual hair follicles were observed in the deep dermis. Subcutaneous vascular dilation, congestion and edema were evident; however, the tissue structure was not destroyed (Fig. 1C). Thus, it was determined that the damage caused by $12 \mathrm{sec}$ hot water contact was equivalent to a deep second-degree burn. Deep second-degree burns were produced on the four hamsters that received hot water contact for $12 \mathrm{sec}$. There were no signs of infection during wound healing and re-epithelialization was complete after 18 days (Fig. 1D). These results indicated that a hamster model of deep second-degree burn was established by applying hot water contact for $12 \mathrm{sec}$.

Chymase activity and $m R N A$ expression levels increase in mast cells after burning and may be involved in the process of burn wound healing. A radioimmunoassay and qPCR were used to investigate the activity and mRNA expression levels of chymase in the burn tissues. Chymase activity was observed in all the post-burn stages and was significantly higher in the burnt tissue when compared with the normal skin tissue (day 0). However, there were no statistically significant differences in chymase activity amongst the various post-burn stages ( $\mathrm{P}>0.05$; Fig. 2A). At days 1, 3, 7 and 14 after burning, chymase mRNA expression levels were significantly higher when compared with those in the normal skin tissue (day 0; $\mathrm{P}<0.05)$. In addition, no statistically significant differences were observed amongst the chymase mRNA expression levels of the post-burn stages ( $\mathrm{P}<0.05$; Fig. 2B). These results demonstrated that chymase activity and mRNA expression levels were increased in the mast cells of the burned tissue and may be involved in the process of burn wound healing.

\section{Discussion}

Hamsters were selected as experimental animals to study chymase activity, as the AngII generated by chymase differs between species, but is similar in humans and hamsters. The burns may easily have been fatal to the hamsters; however, the temperature of the water was controlled and the burn area selected was easy to manipulate. Thus, hot water at $75^{\circ} \mathrm{C}$ was used to produce deep second-degree burn wounds on the hamsters.

Kim et al (26) used continuous scan laser Doppler vibrometry to observe the microvascular perfusion conditions of large-area deep burn wounds in mice and determined the degrees of the burn wounds according to the recovery of the mice. Second-degree burns developed into third-degree burns if the fluid resuscitation rate was $\leq 4 \mathrm{ml} / \mathrm{kg} / \%$ burn. The optimal fluid resuscitation rate was $4-8 \mathrm{ml} / \mathrm{kg} / \%$ burn and the perfusion peak was $6 \mathrm{ml} / \mathrm{kg} / \%$ burn. In the present study, the burn wounds were washed with water for 5 min to reduce the residual heat. In addition, 1.5-1.8 $\mathrm{ml}$ normal saline ( $6 \mathrm{ml} / \mathrm{kg} / \%$ burn) was administered via intraperitoneal injection for fluid resuscitation in order to reduce the exacerbation of the depth of the wounds.

In the present study, the burn area was $7.1 \mathrm{~cm}^{2}$, accounting for $5-6.5 \%$ of the body surface area, which was large enough for the requirements of the study. All hamsters used in the study survived. In addition, no wound infection or other complications were found during the healing process of the deep second-degree wounds. The wounds produced by contact with $20 \mathrm{ml}$ hot water $\left(75^{\circ} \mathrm{C}\right)$ in a $50-\mathrm{ml}$ syringe on the skin of the hamsters for $12 \mathrm{sec}$ satisfied the requirements of a deep second-degree burn wound.

Chen et al (27) used qPCR to detect the mRNA expression levels of cardiac chymase in a hamster model of heart failure, while Guo et al (28) did the same in ovalbumin-stimulated atherosclerosis hamsters. Matsumoto et al (29) used qPCR to detect the mRNA expression levels of chymase in dogs with tachycardia-induced heart failure following the administration of the chymase inhibitor, SUNC8257. Notably, the present study observed increased chymase activity and mRNA expression levels in the hamsters during the process of burn wound healing when compared with the levels prior to the burns. Chymase activity and mRNA expression levels during the healing process were significantly increased when compared with the levels prior to the burn model establishment $(\mathrm{P}<0.05)$, while those in different post-burn stages showed no statistically significant differences $(P>0.05)$. The increased chymase activity in the burn tissue may have been caused by a burn-induced stress response in the hamsters, in which the burns directly acted on the mast cells, activating them to increase degranulation and release chymase. In addition, the burns caused increased vascular permeability, and inflammatory responses increased the numbers and sustained activation of mast cells in the burn wounds.

In conclusion, the results of the present study indicate that chymase is involved in the process of burn wound healing. These results may provide experimental evidence for elucidating the process of burn wound healing and aid the development of new treatment methods for burn wounds.

\section{Acknowledgements}

This study was supported by the Youth Science Foundation of the First Affiliated Hospital of Xinjiang Medical University (no. 2012QN02).

\section{References}

1. Martin P: Wound healing - Aiming for perfect skin regeneration. Science 276: 75-81, 1997.

2. Singer AJ and Clark RA: Cutaneous wound healing. N Engl J Med 341: 738-746, 1999.

3. Akbari H, Fatemi MJ, Iranpour M, et al: The healing effect of nettle extract on second degree burn wounds. World J Plast Surg 4: 23-28, 2015.

4. Domergue S, Jorgensen C and Noël D: Advances in research in animal models of burn-related hypertrophic scarring. J Burn Care Res: Oct 29, 2014 (Epub ahead of print).

5. Räntfors $\mathrm{J}$ and Cassuto $\mathrm{J}$ : Role of histamine receptors in the regulation of edema and circulation postburn. Burns 29: 769-777, 2003. 
6. Santos FX, Arroyo C, García I, et al: Role of mast cells in the pathogenesis of postburn inflammatory response: reactive oxygen species as mast cell stimulators. Burns 26: 145-147, 2000.

7. el Sayed SO and Dyson M: Responses of dermal mast cells to injury. J Anat 182: 369-376, 1993.

8. Hebda PA, Collins MA and Tharp MD: Mast cell and myofibroblast in wound healing. Dermatol Clin 11: 685-696, 1993.

9. Kovanen PT: Mast cells: multipotent local effector cells in atherothrombosis. Immunol Rev 217: 105-122, 2007.

10. Zhao XY, Zhao LY,Zheng QS, et al: Chymase induces profibrotic response via transforming growth factor-beta1/Smad activation in rat cardiac fibroblasts. Mol Cell Biochem 310: 159-166, 2008.

11. Maruichi M, Takai S, Sugiyama T, et al: Role of chymase on growth of cultured canine Tenon's capsule fibroblasts and scarring in a canine conjunctival flap model. Exp Eye Res 79: 111-118, 2004

12. Saarinen J, Kalkkinen N, Welgus HG and Kovanen PT: Activation of human interstitial procollagenase through direct cleavage of the Leu83-Thr84 bond by mast cell chymase. J Biol Chem 269: 18134-18140, 1994.

13. Doggrell SA and Wanstall JC: Vascular chymase: pathophysiological role and therapeutic potential of inhibition. Cardiovasc Res 61: 653-662, 2004.

14. Nishikori Y, Kakizoe E, Kobayashi Y, et al: Skin mast cell promotion of matrix remodeling in burn wound healing in mice: relevance of chymase. Arch Dermatol Res 290: 553-560, 1998.

15. Dong X, Chen J, Zhang Y and Cen Y: Mast cell chymase promotes cell proliferation and expression of certain cytokines in a dose-dependent manner. Mol Med Rep 5: 1487-1490, 2012.

16. Wintroub BU, Schechter NB, Lazarus GS, Kaempfer CE and Schwartz LB: Angiotensin I conversion by human and rat chymotryptic proteinases. J Invest Dermatol 83: 336-339, 1984

17. Takai S, Shiota N, Jin D and Miyazaki M: Functional role of chymase in angiotensin II formation in human vascular tissue. J Cardiovasc Pharmacol 32: 826-833, 1998.

18. Caughey GH, Raymond WW and Wolters PJ: Angiotensin II generation by mast cell alpha- and beta-chymases. Biochim Biophys Acta 1480: 245-257, 2000.
19. Schildt B and Nilsson A: Standardized burns in mice. Eur Surg Res 2: 23-33, 1970.

20. Somboonwong J, Kankaisre M, Tantisira B and Tantisira MH: Wound healing activities of different extracts of Centella asiatica in incision and burn wound models: an experimental animal study. BMC Complement Altern Med 12: 103, 2012.

21. Ramos-Gallardo G, Ambriz-Plascencia AR and González-Reynoso L: Systemic steroids use in second-degree burn using an animal model. Rev Med Inst Mex Seguro Soc 50: 9-12, 2012 (In Spanish).

22. Gaines C, Poranki D, Du W, Clark RA and Van Dyke M: Development of a porcine deep partial thickness burn model. Burns 39: 311-319, 2013

23. Kempf M, Cuttle L, Liu PY, Wang XQ and Kimble RM: Important improvements to porcine skin burn models, in search of the perfect burn. Burns 35: 454-455, 2009.

24. Cuttle L, Kempf M, Phillips GE, et al: A porcine deep dermal partial thickness burn model with hypertrophic scarring. Burns 32: 806-820, 2006.

25. Cribbs RK, Luquette MH and Besner GE: A standardized model of partial thickness scald burns in mice. J Surg Res 80: 69-74, 1998.

26. Kim DE, Phillips TM, Jeng JC, et al: Microvascular assessment of burn depth conversion during varying resuscitation conditions. J Burn Care Rehabil 22: 406-416, 2001.

27. Chen W, Yu MH, Li YM, Chen WJ and Xia YP: Beneficial effects of astragalus polysaccharides treatment on cardiac chymase activities and cardiomyopathy in diabetic hamsters. Acta Diabetol 47 (Suppl 1): 35-46, 2010.

28. Guo T, Chen WQ, Zhang C, Zhao YX and Zhang Y: Chymase activity is closely related With plaque vulnerability in a hamster model of atherosclerosis. Atherosclerosis 207: 59-67, 2009.

29. Matsumoto T, Wada A, Tsutamoto T, Ohnishi M, Isono T and Kinoshita M: Chymase inhibition prevents cardiac fibrosis and improves diastolic dysfunction in the progression of heart failure. Circulation 107: 2555-2558, 2003. 